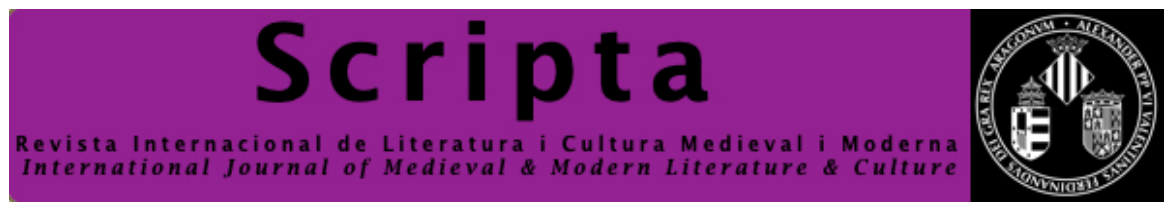

\title{
Judes-Èdip en l'edat mitjana
}

\author{
Judas-Oedipus in the Middle Ages
}

\author{
Albert Toldrà i Vilardell \\ albert.toldra@uv.es
}

Universitat de València

\begin{abstract}
Resum: Una llegenda medieval fon dos personatges literaris: el Judes dels evangelis i l'Èdip clàssic de la tragèdia de Sòfocles, de manera que ens trobem un Judes que, a més dels pecats que ja li coneixíem (traïció, avarícia, mentida, satanisme, suïcidi etc.), comet dues transgressions "edípiques": el parricidi mata el seu pare-i l'incest -es casa amb sa mare. En aquest article fem un seguiment de la tradició textual d'aquesta fussió, del s. XII al XVI, en especial a través de les "passions" teatrals occitanes i catalanes, la Legenda aurea de Varazze i algunes referències de sant Vicent Ferrer i Francesc Eiximenis.
\end{abstract}

Paraules clau: Judes, Èdip, passions, incest, parricidi.

Abstract: A medieval legend joins two literary characters: the Judas from gospels and the classical Oedipus from the Sophocles tragedy; we find so a Judas that, in addition to the sins that we already know (treason, avarice, lie, satanism, suicide etc.), commits two "oedipical" transgressions: parricide -he kills his father- and incest -he marries his mother. In this article we follow the textual tradition of this fussion, from XIIth century to XVIth, particularly over the occitan and catalan theatrical "passions", the Varazze's Legenda aurea and some references from saint Vincent Ferrier and Francesc Eiximenis.

Keywords: Judas, Oedipus, passions, incest, parricide. 
Són ben conegudes les estranyes metamorfosis que pateixen els mites adoptats per la cultura llibrària de l'Edat Mitjana; tant els heretats de l'antiguitat clàssica com els importats d'orient o dels mateixos textos bíblics. Farem una ullada a un aspecte de la llegenda medieval de Judes Iscariot. El jove Judes hi pateix un curiós procés d"'edipització": en alguns textos catalans medievals ens trobem, efectivament, amb una significativa fussió del nostre personatge amb l'Èdip hel lènic de la tragèdia de Sòfocles.

Els elements de la llegenda: un somni premonitori de la mare de Judes (o la matança dels innocents, a les versions més antigues) provoca l'abandonament del nadó a l'aigua (o al bosc); el nadó és marcat de manera que possibilitarà el seu reconeixement posterior; ja crescut Judes, involuntàriament mata el seu germanastre i després comet parricidi i incest.

Però aquesta versió no apareix als evangelis sinòptics, ni tampoc als dos apòcrifs que recullen la història de Judes, el de Tacià i el d'Ammoni, que segueixen fil per randa les versions de la Bíblia. I tampoc no sembla possible una trasmissió oral directa des de la Grècia clàssica fins al s. XIII.

D’on prové, doncs, aquest reciclatge de la història d'Ėdip? O podria tractar-se d'una llegenda d'origen popular, sense cap relació amb el mite grec, d'una coincidència? La questió va ser estudiada ara fa un segle per Paull Baum i, en l'àmbit català, per Josep Romeu i Figueras -els estudis clàssics-; i més modernament, per Carles Riba ${ }^{1}$, Lehmann, Paffenroth i Brisset, entre altres. És un problema insoluble de moment.

D’una banda, Èdip era conegut a l'edat mitjana, sobretot a través de les versions del Roman de Thebes (ca. 1150), però no sols per elles: apareix també en alguns poemes trobadorescos. I de fet, Baum raona que la llegenda de Judes, en especial a les versions més antigues, es pot interpretar perfectament com una medievalització de l'argument clàssic de la tragèdia de Sòfocles, substituint l'oracle pagà per un somni o per la matança dels innocents com a motiu per a l'exposició del nen.

Però la hipòtesi de la coincidència també és plausible, com va plantejar Paull Baum: en la possibilitat d'una elaboració popular de l'argument, entra en la lògica medieval suposar-li a Judes una vida de terribles pecats anterior al seu "fitxatge" com a apòstol. Quins pecats més terribles que la transgressió de dos dels tabús més profunds de la cultura occidental, parricidi i incest? Però per a fer-los possible cal un allunyament previ del xiquet, l'abandonament del nadó, ben freqüent a la literatura medieval, amb el model bíblic de Moisès. Existeixen mites semblants a tradicions culturals diverses, i d'altra banda l'incest és un tema obsessiu als segles XI i XII, quan l'Església emprén una campanya per cristianitzar el matrimoni i lluitar contra la tendència endogàmica de la noblesa. Aquest suposat origen popular d'aglutinació de pecats no seria, diu Baum, contradictori amb la transmissió escrita posterior.

1 Carles Riba dóna per fet que l'origen de la llegenda de Judes és la tragèdia de Sòfocles, a la seua introducció a les tragèdies de Sòfocles (Riba 1959: vol.II, 91). 
Quant a la transmissió textual de la llegenda, diversos autors assenyalen un fragment d'Orígenes, al seu Contra Celsum (s. III), en què esmenta tots dos, Judes i Èdip, al mateix paràgraf, en una reflexió sobre el destí i el lliure albir, com el possibli inici, allò que podria haver inspirat el redactor de la llegenda. Predomina entre els investigadors l'opinió d'un origen greco-siríac i una primitiva traducció llatina desapareguda, que faria de pont amb les versions medievals més antigues conegudes.

El manuscrit més antic que conservem ${ }^{2}$ és de la segona meitat del s. XII, en llatí, provinent de St. Victor, a França. En aquesta versió, Judes és abandonat per sa mare al bosc per salvar-lo de la matança dels innocents; assassina sense saber-ho el seu pare en furtar una poma per Herodes (ilium percussit et occidit), i es casa també sense saber-ho amb sa mare (uxorem interfecti Iude copulavit). Hi manquen o canvien diferents elements respecte a les versions posteriors: l'abandonament a l'aigua, el fraticidi i la marca que permetrà el reconeixement de Judes per sa mare.

Aquesta versió "primitiva" -el text A, en l'esquema de Baum-, és reproduïda en una trascripció gascona del s. XIV, de l'anomenat manuscrit Didot ${ }^{3}$, que ja inclou, però, l'abandonament a l'aigua i els senyals físics pels quals Judes és reconegut (enans de sisque / ma mayre en laygua 'm gites/ mi fe i. ceyal en l'asquina). L'emparellament de Judes amb sa mare, a diferència del manuscrit llatí, té lloc espontàniament, sense cap relació amb el parricidi: Ma mayre azautec se de mi / e heu d'ela atresi,/ de tal guiza nos azautem / que aqui meteys nos ajustem (...) nos aguem.ii. enfans agut / que encara no'us fom conogut.

I el reconeixement es produeix pels senyals:

E une vet can fom colocat, / ela'm toquec tost los costat/ e cone ( $t$ ) me aquel seyal (...) "Amic, tu es mo filh (...) sapias que eel que as ausit/ era ton payr (...) asat me semlas desastruc, / car ab ta mayre as yagut,/ e ton payre que aias mort,/ fort deus aver gran desconort,/ car home ab ta gran pecat/ no crey pogues ecer trobat."

La llegenda edípica de Judes s'escampa per tot Europa occidental: al s. XIII, encara en llatí; Varazze l'adopta, la qual cosa contribueix a la seua divulgació, tot i que subsistiran versions anteriors divergents; al s. XIV la trobem ja traduïda a diferents llengües; les primeres versions en llengua vulgar, de finals del s. XIII, són la bohèmia, la galesa i la catalana, que alhora marquen l'abast geogràfic del mite.

La Legenda Aurea, la recopilació clàssica medieval de vides de sants, escrita per Jacopo da Varazze -Vorágine a les versions castellanes- al s. XIII, recull; en faig servir la versió llatina (Varazze 1480: f.38r. i s.) i la catalana, les Vides de sants rosselloneses (Varazze 1977: 282-286). Es tracta d'una versió edipitzada, inclosa en la vida de sant Macià, l'apòstol que substitueix Judes Iscariot després de la seua baixa definitiva al col legi apostòlic. Evidentment, un personatge com Judes no mereixia una Vida pròpia. Varazze cita com a font, sense precisar, una història "apòcripha”. Es tracta d'una magnífica biografia prèvia als fets evangèlics; Varazze ens adverteix però, en una breu nota al final de la seua prolixa narració, que considera fals el fragment que acaba d'immortalitzar: "una ystòria, qui no és

2 París, Bibliothèque Nationale, lat. 14489. Citat per Baum, 1916: 485.

3 París, Bibliothèque Nationale, nouv. aqc. fr. 4232. Citat per Baum, 1916: 553 i s. 
creseguda". Apel la, per tant, al criteri dels lectors: lectoris arbitrio relinquit.

Heus ací el resum, remarcant-ne els abundants paral lelismes argumentals, molt del gust medieval: Judes és fill de Rubén (o Simó, segons sant Joan), de la tribu de Dan (com l'Anticrist), i de Ciborea, nom que sembla basat en el de la mare de Moisès, Zipporah. Aquesta, prenyada, té un somni en què és avisada de la perfídia del fill que ha de parir: "enfant mot malvat e omesier, qui serà causa de perdement de tota la nostra gent". Com que no gosen de matar-lo, "lo gitaren en la mar" (com Moisès), però en aquesta versió el nadó no és marcat. El petit Judes arriba en una illa, "Escariot", on la reina el troba i l'adopta. En créixer, mata el seu germanastre i hereu del regne (com Caïm) i fuig a Jerusalem, on es posa al servei de Pilat -no Herodes, com a la versió primitiva-, qui arriba a apreciar-lo força. Per complaure el seu senyor, Judes entra a l'hort veí al palau per robar unes pomes; es baralla amb l'amo del camp, que resulta ésser Rubén, son pare, i el mata accidentalment. Pilat li lliura llavors les riqueses del mort, i el casa amb la vídua, sa mare (in coningem copulavit). Infringeix, doncs, d'una tacada, els tabús de parricidi $\mathrm{i}$ incest: inventum est quod Iudas matrem suam in uxorem duxerit, quod patrem suum occiderit. Assabentat de la veritat Judes, penedit, renuncia al pecat i entra a servir Crist, que el perdona i el fa deixeble seu.

Aquesta versió edipitzada de la Legenda tingué una immensa difusió per l'Europa medieval, en especial al teatre religiós occità i català, les "passions" (Teatre català antic, 1994: vol. I, 97-143). La més antiga conservada que la conté -la primera en el teatre europeu en llengua vulgar- és una passió catalana del s. XIV de la qual conservem fragments, que inclouen el monòleg (Mt 26; Mc 14; Lc 7; Io 12) on Judes, enfadat pel malbaratament que fa Maria Magdalena de l'ungüent preciós, narra la seua vida abans de ser apòstol. Aquesta versió, segons Baum, és propera de la més antiga, tot i que s'hi diferencia en què l'abandonament no és al bosc sinó al riu -"per l'aygua aval"-, apareix la marca física però no la mort del germanastre; la unió amb la mare tampoc no és relaciona amb el parricidi, i es descriu el reconeixement, gairebé amb les mateixes paraules que hem vist a la versió occitana: "ma mayre adauté's de mi/ et eu d'ela mot atressií./ De tal guisa nos asautem,/ aquí mateix nos aplaguem (...) Ela m va palpar mos costatz/ e conec aquel senyal/ que ela y fé ab ferre calt (...)"

La representació coneguda com "Passió de Cervera" (Sança 1994: 34), del 1534, en canvi, sembla basar-se més en la versió de Varazze: abandonament al mar -no al riu-, no hi ha el senyal físic però sí l'assassinat del germanastre:

"Yo tota ma vida/ só stat nefandíssim (...) i só jo dels hòmens/ lo més perversíssim (...) Ha!, que xiquet/ en mar me llançaren/ i dins la gran aigua/ negar no em poguí(...) lo fill de la reina/ sens por matí jo (...) la sanch verdadera/ del natural pare/ scampí sens rahó./ Aprés, per complir/ millor tal errada,/ casím ab la mare/ qui m va aleytar”.

Una intervenció posterior en aquesta passió censura una part del monòleg de Judes; substitueix la referència a parricidi i incest per: "Car a mon pare jo matí/ Y ab ma mare me bolguî". Aquest fet de censurar el text medieval, "l'apòcrifa i truculenta llegenda", en paraules de Romeu i Figueras, serà una constant a partir del s. XVI.

Pel que fa a les passions mallorquines, la versió edípica apareix en la tercera del manuscrit de les 
consuetes $^{4}$. El monòleg de Judes, ací, no prové de Varazze sinó d'altres versions anteriors, ja que el nadó és abandonat per salvar-lo de la matança dels innocents i s'hi inverteix l'ordre cronològic del parricidi i l'incest: "En ma mare jo he dormit/ Y a mon pare he ferit/ Y he mort a qui m'à creat". Brisset afirma que, si bé el manuscrit és del s. XVI, el text d'aquesta consueta dataria del s. XIII, amb la qual cosa es tractaria de la versió més antiga europea en llengua vulgar.

Aquest mateix argument arcaic el trobem en l'altra passió mallorquina que recull la llegenda edípica, ja del s. XVIII: "prenguí muller/ y fou ma mare, ab gran plaer/ conexent-la carnalment (...) Després mon pare vaig matar/ per a poder-me més folgar".

No sols al teatre; sant Vicent Ferrer -i això és l'aportació original d'aquesta intervenció- també recull la versió edípica de Judes, de manera telegràfica i només una volta -almenys no n’he trobat més referències al conjunt dels seus sermonaris publicats en català, castellà i llatí-. És al número XXXIX dels Sermons de quaresma editats per Sanchis Guarner, seguint el text establert per Sanchis Sivera, sermó predicat per sant Vicent a la ciutat de València la quaresma de l'any 1413, immediatament després de la seua participació al Compromís de Casp.

Sabem que una de les fonts abundantment emprades pel predicador fou la Legenda aurea, d'on probablement va traure aquest argument: Judes havia comès, abans d'ésser apòstol, parricidi i incest, sense més detalls. El tema que dóna peu a la narració és el desagraïment, d'altra banda impregnat d'antisemitisme:
(...) retre mal per bé: açò va mal de tot, que és condició diabolical. Judes Iscariot havia mort son pare, e havia jagut ab sa mare, e Jesucrist perdonà-li tots sos pecats, e pres-lo en deixeble e apòstol, e com fos ignorant, li donà ciència, e que pogués il luminar cecs; e lo traïdor, per bé, reté mal. "Nonne ego elegi duodecim: et unus ex vobis diabolus est" (Jo, 6, 71): hoc dicebat de Judes Iscariot. Així, guardats-vos-ne, de retre, per bé, mal. E així eren los jueus, que per bé retien mal (Ferrer 1973: vol. II, 113).

Però els avatars medievals de Judes no es limiten a Ėdip: també ens trobem una versió "prometeïca". Es tracta d'una variant de la condemna de Judes. La relata Benedeit, arquebisbe poeta de la cort anglonormanda d'Enric I, fill de Guillem el Conqueridor, cap al 1106. El text és el Viatge de sant Brendan (Benedeit 1983: 44 i s.), que conta les navegacions prodigioses d'aquest sant pel més enllà. Malgrat que se li suposa a la llegenda un origen celta, Benedeit segueix un text llatí, la Navigatio Sancti Brendanni Abbatis, produït al s. X en un monestir germànic de la Lotaríngia otònida.

Prop de l'illa atlàntica on és l'infern, Brendan i els seus companys troben una roca emergida, damunt la qual hi ha un home despullat, recolzat en una columna per no ser arrossegat per les ones. Interrogat per Brendan, l'home declara ésser Judes Iscariot, el qual relata detingudament les seues maldats i els turments que pateix. Però resulta que també havia fet bones accions, com ara la

4 Barcelona, Biblioteca de Catalunya, ms. 1139, consuetes 38 i 39. Citat per Romeu 1994: 126 i 134. 
construcció d'un pont (els ponts medievals, com és sabut, tenen estreta relació amb el dimoni), i per això disfruta de mitigacions en el seu càstig: aquest és el seu lloc de descans de les penes de l’infern, on ve cada diumenge, la quinzena de Nadal, festes marianes, Pasqua i Pentecostés; un més enllà regit pel calendari litúrgic eclesiàstic, cosa que ens recorda la continuïtat medieval entre el món dels vius i el dels morts.

Aquesta versió amb un Judes prometeïc la recollira, tres segles més tard, Francesc Eiximenis, amb alteracions però mantenint la localització marítima, l'heterodoxa mitigació de les penes infernals de Judes, i la causa, el pont. El viatger, en la versió d'Eiximenis -que no apareix a la Legenda-, és ara sant Cebrià, "navegant en les partides d'Orient". En una illa, el sant troba Judes, a la vora d'un pou:

Io (...) só fort turmentat en infern, contínuament, a tots los altres dies exceptat lo disabte, que'm traen per aquest pou, e repòs ací per guardó de una obra de caritat que fiu en mon jovent a la cosa pública, ans que m'acostàs a la companyia del Salvador (Eiximenis 1929: 120).

El benefici que havia fet Judes era reparar un pont. El polític Eiximenis el que pretén ací és emfasitzar les recompenses espirituals atorgades per les bones accions cap a la cosa pública.

Per acabar aquesta tediosa exposició, trobe que cal relacionar l'edipització de Judes amb algunes característiques de la mentalitat medieval. En primer lloc, la tendència a l'horror vacui, en aquest cas a farcir els buits de les biografies dels personatges evangèlics amb elements apòcrifs, en ocasions construint autèntiques novel les sense cap base real; recordem, per posar un altre cas notori, el de Maria Magdalena. Encara una altra llegenda sobre la infància de Judes diu que es va trobar amb Jesús, tots dos xiquets, i Judes el va mossegar al pit, on anys després li clavarien la llança. Aquest interessant avenç de la relació entre tots dos personatges és a l'anomenat evangeli àrab de la infància, 35 (Los evangelios apócrifos 1999: 323).

Un altre element vinculat és la satanització del paganisme clàssic. De la mateixa manera que els conqueridors espanyols d'Amèrica identifiquen sense problemes els déus precolombins i els seus servidors com a dimonis, també els déus de l'antiguitat clàssica es converteixen en diables, i en la iconografia gòtica els ídols són representats directament com a dimonis. En el cas que ens ocupa, la noció tràgica del destí desapareix, substituïda per la moral: parricidi i incest són pecats, grans pecats.

I les simetries. Els jocs d'espills conceptuals són una de les eines preferides de l'especulació medieval -recordem que els tractats genèrics són anomenats precisament així, Speculum, Espill. Callois (Callois 1982: 261) explica en un estudi de sociologia històrica com en l'antic règim el rei i el botxí representen les dues cúspides de la doble piràmide de l'imaginari social, dos extrems inversos però directament vinculats $\mathrm{i}$ amb determinats elements comuns, fins que tots dos són abolits per la guillotina revolucionària. Aplicant aquest esquema interpretatiu de Callois 
al cristianisme medieval, ocorre el mateix amb la parella Crist-Judes: un és l'invers a l'altre, negatiu i complementari, fins i tot necessari -segons el recentment aparegut evangeli de Judes (The gospel of Judas 2006). Crist és dalt del cel, al costat de Déu pare, mentre Judes rau a l'infern més profund, segons Dante dins la boca de Llucifer: Quell'anima là sù c’ha maggior pena (...) è Giuda Scariotto (Inferno: XXXIV, 55).

Aquest Judes antítesi de Crist lògicament aglutina, com acabem de veure, tot el mal i el pecat, totes les transgressions a la moral cristiana: hebraisme, satanisme, avarícia, furt, traïció, fraticidi, parricidi, incest, suïcidi. El Judes medieval té, doncs, un caràcter maligne i aglutinant, a diferència del mite clàssic d’Èdip, que era una digna víctima del fatum. 


\section{Textos}

Benedeit (1983), El viaje de san Brandán. Ed. M. J. Lemarchand, Madrid, Siruela.

Alighieri, D. (2000), Divina comèdia. Trad. J. F. Mira, Barcelona, Proa.

Eiximenis, F. (1929) Doctrina compendiosa, Barcino, Barcelona

Ferrer, V. (1973), Sermons de Quaresma, Ed. M. Sanchis Guarner. vol. II, València, Albatros.

Kasser, R. \& Meyer, M. \& Wurst, G. (eds.) (2006) The gospel of Judas, National Geographic Society.

Los Evangelios Apócrifos (1999). Ed. A. Santos Otero, Madrid, BAC.

Massot i Muntaner, J. (ed.) (1994)Teatre medieval i del renaixement, Barcelona, Ed. 62.

Romeu i Figueras, J. (ed.) (1994) Teatre català antic (1994), vol. I, Barcelona, Curial.

Sança, B. \& Ponç, P. (1994) "Misteri de la Passió de Jesucrist" o la "Passió de Cervera", dins Teatre medieval i del renaixement. Ed. J. Massot i Muntaner. Barcelona, Ed. 62.

Varazze, I. de (1480) Legenda Aurea, Venècia, P. Antonio de Strata de Cremona i M. Catanello Schaluicola. [Exemplar conservat a València, Biblioteca General i Històrica de la Universitat de València, inc. 214]

Varazze, I. de (1977) Vides de sants rosselloneses. Ed. Kniazzeh, C. H. S. M. \& Neugard, J. Barcelona, Fundació Salvador Vives Casajoana.

\section{Bibliografia}

Archibald, E. (2001) Incest and the Medieval Imagination, Oxford, Clarendon Press.

Ariès, Ph. i Duby, G. (dirs.) (1987) Historia de la vida privada, vol. II, De la Europa fendal al Renacimiento, Madrid, Taurus.

Baltrusaitis, J. (1994) La Edad Media fantástica. Antigüedades y exotismos en el arte gótico, Madrid, Cátedra.

Baum, P. F. (1916) "The Medieval Legend of Judas Iscariot", Publications of the Modern Language Association of America, XXXI, pp. 481-632.

Brisset Martín, D. E. (2000) “Leyenda y símbolo en el personaje ritual de Judas”, Gaceta de antropología, $n^{\circ} 16$.

Callois, R. (1982) "Sociología del verdugo", A. Hollier (ed.), El Colegio de Sociología (1937-1939), Madrid, Taurus.

Corbin, A. \& Courtine, J.-J. \& Vigarello, G. (dirs.) (2005), Historia del cuerpo, Madrid, Taurus. 
Deschner, K. (1993) Historia sexual del cristianismo, Saragossa, Yalde, .

Flandrin, J.-L. (1981) Le sexe et l'Occident. Évolution des attitudes et des comportements, Seuil.

—_.(1987) "La vida sexual matrimonial en la sociedad antigua: de la doctrina de la Iglesia a la realidad de los comportamientos”, d.a., Sexualidades Occidentales, Barcelona, Paidós.

Murray, M. (2013) Traitor. A Biography of Judas Iscariot, Bookcaps.

Paffenroth, K. (2001) Judas: Images of the Lost Disciple, Louisville-London, Westminster John Knox Press.

Payer, P. J. (1984) Sex and the Penitentials. The Development of a Sexual Code. 550-1150, University of Toronto Press.

Riba, C. (1959) "Notícia preliminar a la tragèdia Édip rei” Sòfocles/ Riba, C. (ed.), Tragèdies. Àiax. Ėdip rei, Barcelona, Fundació Bernat Metge, vol. II, pp. 89-119.

Romeu i Figueres, J. (1994) "La legenda de Judes Isacriot en el teatre català i occità. Assaig de classificació de les Passions dramàtiques catalanes", Teatre Català antic, vol. I, (ed. d'F. Massip i P. Vila), Barcelona, Curial, pp. 97-143.

Stanford, P. (2015) Judas. The troubling history of the renegade apostle, Londres, Hodder \& Stoughton.

Toldrà i Vilardell, A. (2000) Aprés la mort. Un viatge amb sant Vicent al més enllà medieval, València, Editorial $3 i 4$.

—. (2003) "Judes a l'edat mitjana", Afers, fulls de recerca i pensament, 45, pp. 447-462

—.(2010) Mestre Vicent ho diu per espantar. El més enllà medieval, Catarroja, Editorial Afers.

- (2017) El plaer de la carn. Sexe i temperament en la cultura medieval, València, Institució Alfons el Magnànim. 